16 Lok ASF, Novick DM, Karaviannis P, Dunk A, Sherleck S, Themas HC. A randomised study of the effects of adenine arabinoside 5'monophosphat (short or long courses) and lymphoblastoid interferon in hepatitis B viru infection. Heputologv 1985;5:1132-8.

17 Caruso L, Weher J, Forster G, et al. Effects of HTLV III virus infection of $\mathrm{HBV}$ replication, severity of liver disease and response to interferon treatment in chronic hepatitis B virus carriers. $f$ Héputol 1986;3 (suppl 2):207.

18 McDonald JA, Harris S, Waters JA, Thomas HC. Effect of human immunodeficiency virus (HIV) infection in chronic hepatitis B viral antigen display. $\mathcal{J}$ Heputol 1987;4:337-42

19 Krogsgard K, Lindhart OB, Nielson JO, et al. The influence of HTLV-III infection on the natural history of hepatitis $B$ virus infection in male infection on the natural history of hepatitis B virus
homosexual HBsAg carriers. Hepatology 1987;7:37-41.

20 Noonan CA, Yoffe B, Mansell PW, Melnick JL, Hollenger FB. Extrachromosomal sequences of hepatitis B virus DNA in peripheral bloed mononuclear cells of acquired immunodeficiency syndrome patients. Proc Nall Acad Sc USA 1986;83:698-702.

21 Hirschman SZ, Zucker ML. Recombinant DNA related to hepatitis B and human immunodeficiency viruses in mononuclear cells of patients with AIDS. F Med Virol 1988;26:145-52

22 Fischl MA, Richman DD, Grieco MH, et al. The efficacy of azidothrmidine (AZT) in the treatment of patients with AIDS and AIDS-related complex. $N$ Engl I Med 1987;317:192-7.

23 Vento S, Hegarty JE, Alberti A, et al. T lymphocyte sensitisation to $\mathrm{HBCAg}$ and $\mathrm{T}$-cell mediated unresponsiveness to $\mathrm{HBsAg}$ in hepatitis $\mathrm{B}$ virus related chronic liver disease. Hepatology 1985;5:192-7.

24 Hegarty JE, Fagan E, Johnson P. Immunological responses in liver disease. Liver Annual 1985:4:209-38.

25 Waters JA, Pignatelli $M$, Brown D, et al. The immune response to hepatitis $\mathrm{B}$ virus. Postgrad Med f 1987;63 (suppl 2):51-6.

26 Ferrari C, Penna A, Degli-Antoni A, Fiaccodori F. Cellular immune response to hepatitis B virus antigens. $\mathcal{F}$ Hepatol 1988;7:21-3.
27 Pignatelli M, Waters J, Lever A, I warson S, Gerety R, Thomas HC. Cytotoxic T-cell responses to the nucleocapsid proteins of $\mathrm{HBV}$ in chronic hepatitis. $\mathcal{f}$ Hepatol 1987;4:15-21.

28 McDonald JA, Caruso L, Karayiannis P, et al. Diminished responsiveness of male homosexual carriers with HTLV-III antibodies to recombinant alfa interferon. Heputology 1987;3:719-23.

29 Novick DM, Lok ASF, Thomas HC. Diminished responsiveness of homosexual men to antiviral therapy for $\mathrm{HBsAg}$ positive chronic liver disease. $\mathcal{f}$ Hepatol 1985; 1:29-35.

30 Von Wussow P, Hartman F, Freund M, Poliwoda H, Deicher H. Leucocyte derived interferon alpha in patients with antibodies to recombinant IFNderived interferon alpha in

31 Steers RG, Smith JW, Urba WJ, et al. Resistance to recombinant interferon alfa $2 \mathrm{a}$ in hairy cell leukemia associated with neutralising anti-interferon alfa 2a in hairy cell leukemia associated with

32 Finter NB. The classification and biological functions of the interferons. $f$ Hepatol 1986;3(suppl 2):S157-60.

33 Billau $A$. The mode of action of interferons in viral infections and their possible role in the control of hepatitis B. F Hepatol 1986;3(suppl 2):S171-9.

3t Morris A, Cooley $M$, Blackman $M$. The interaction of interferon with th immune response. f Heputol 1986;3(suppl 2):S161-9.

35 Perrillo RP, Regenstein FG, Peters MG, et al. Prednisone withdrawal followed by recombinant alfa interferon in the treatment of chronic type $B$ hepatitis. Ann Intem Med 1988;109:95-100.

36 Brook MG, Petrovic L, McDonald JA, Scheuer PJ, Thomas HC. Histological improvement after antiviral treatment for chronic hepatitis B virus infection. f Heputol 1989:8:218-25.

37 Scullard GH, Andres LL, Greenterg HB, et al. Antiviral treatment of chronic hepatitis $B$ virus infection: improvement in liver disease with interferon and adenine arabinoside. Heputology 1981;1:228-32.

(Accepted 21 fuly 1989)

\section{Post-transfusion hepatitis in Trent Regional Health Authority, 1988}

\section{P Flanagan, P Nuttall, V James}

Trent Regional Blood

Transfusion Centre,

Sheffield S5 7JN

P Flanagan, MRCPATH, senior

registrar

P Nuttall, SRMLT, head of

microbiology

V James, FRCPATH,

consultant haematologist

Correspondence to:

Dr Flanagan.

BrMed f 1989;299:656-7

Post-transfusion hepatitis still occurs in the United Kingdom despite the introduction of sensitive assays for hepatitis B surface antigen. Only a small proportion of cases of hepatitis transmitted by transfusion is recognised by doctors and reported to regional transfusion centres. ${ }^{1}$ Furthermore, non-A, non-B hepatitis is the predominant type transmitted by transfusion and probably accounts for more than $90 \%$ of cases. ${ }^{2}$ We studied all cases of suspected post-transfusion hepatitis reported to this centre in one year and investigated the donors in these cases for markers of hepatitis infection.

\section{Subjects, methods, and results}

During 1988 six cases of suspected post-transfusion hepatitis were reported to this centre; five were cases of hepatitis $B$ and one of non-A, non-B hepatitis. Three of

Results of serological testing for markers of hepatitis infection in donors who had donated blood given to six patients who developed hepatitis $B$ or non- $A$, non- $B$ hepatitis

\begin{tabular}{|c|c|c|c|c|c|c|}
\hline \multirow[b]{2}{*}{$\begin{array}{l}\text { Case } \\
\text { No }\end{array}$} & \multirow[b]{2}{*}{$\begin{array}{c}\text { Type } \\
\text { of } \\
\text { hepatitis }\end{array}$} & \multirow[b]{2}{*}{$\begin{array}{c}\text { No } \\
\text { of } \\
\text { donors }\end{array}$} & \multicolumn{3}{|c|}{ Results of serological testing of donors for: } & \multirow[b]{2}{*}{$\begin{array}{c}\text { History of } \\
\text { hepatitis } \\
\text { in donors }\end{array}$} \\
\hline & & & $\begin{array}{c}\text { Hepatitis B } \\
\text { surface } \\
\text { antigen }\end{array}$ & $\begin{array}{c}\text { Hepatitis B } \\
\text { core } \\
\text { antibody }\end{array}$ & $\begin{array}{c}\text { Hepatitis B } \\
\text { surface } \\
\text { antibody }\end{array}$ & \\
\hline \multicolumn{7}{|c|}{ Hepatitis not transmitted by transfusion } \\
\hline $\begin{array}{l}1 \\
2 \\
3\end{array}$ & $\begin{array}{l}\text { B } \\
\text { B } \\
\text { B }\end{array}$ & $\begin{array}{l}4 \\
1 \\
2\end{array}$ & $\begin{array}{l}3 \text { Negative, 1 ND } \\
\text { Negative } \\
2 \text { Negative }\end{array}$ & $\begin{array}{l}2 \text { Negative, } 2 \mathrm{ND} \\
\text { Negative } \\
2 \text { Negative }\end{array}$ & $\begin{array}{l}\text { ND } \\
\text { ND } \\
\text { ND }\end{array}$ & $\begin{array}{l}\text { No } \\
\text { No } \\
\text { No }\end{array}$ \\
\hline \multicolumn{7}{|c|}{ Hepatitis probably transmitted by transfusion } \\
\hline 4 & B & 4 & 4 Negative & $\left\{\begin{array}{l}3 \text { Negative } \\
1 \text { Positive }\end{array}\right.$ & $\begin{array}{l}\text { ND } \\
\text { Negative* }\end{array}$ & $\begin{array}{l}\text { No } \\
\text { Yes }\end{array}$ \\
\hline 5 & B & 4 & 4 Negative & $\left\{\begin{array}{l}3 \text { Negative } \\
1 \text { Positive }\end{array}\right.$ & $\begin{array}{l}\text { ND } \\
\text { Negative* }\end{array}$ & $\begin{array}{l}\text { No } \\
\text { Yes }\end{array}$ \\
\hline 6 & Non- $A$, non-B & 2 & 2 Negative & $\left\{\begin{array}{l}1 \text { Negative } \\
1 \text { Positive }\end{array}\right.$ & $\begin{array}{l}\text { ND } \\
\text { Weakly positive }\end{array}$ & $\begin{array}{l}\text { No } \\
\text { No }\end{array}$ \\
\hline
\end{tabular}

$\mathrm{ND}=$ Not done

${ }^{\star}$ Result negative by haemagglutination test but low levels of antibody detected by radioimmunoassay. the cases of hepatitis B infection formed a cluster in one hospital in the region, and investigations performed by the Public Health Laboratory Service yielded a common source of infection not related to blood transfusion. These three cases were therefore not due to transfusion. The infection in the other three cases seemed to have been transmitted by transfusion.

The donors implicated in all six episodes were contacted and samples obtained for testing for markers of hepatitis B infection. Samples were obtained from 16 of the 17 donors either in response to postal contact or after redonation; one donor (case 1) did not respond to postal contact. The table gives the results. Hepatitis B surface antibody was sought only in donors positive for hepatitis B core antibody. In addition, alanine aminotransferase activity was measured in the two donors who might have transmitted non- $A$, non-B hepatitis infection; it was within the normal range in both.

In each of the three cases of disease probably related to transfusion one donor was shown to be positive for hepatitis B core antibody. Furthermore, in the two cases of hepatitis B probably related to transfusion the donors positive for hepatitis B core antibody gave histories of acute hepatitis two to three years before donation.

\section{Comment}

Transmission of hepatitis B by transfusion of blood negative for hepatitis $B$ surface antigen but positive for hepatitis B core antibody has been reported. ${ }^{3}$ Donors who are negative for hepatitis $B$ surface antibody have been shown to confer the greatest risk, but there is circumstantial evidence of transmission of hepatitis B by donors with both hepatitis B core antibody and low levels of hepatitis B surface antibody. ${ }^{+}$Screening for hepatitis B core antibody and measurement of alanine aminotransferase activity are used in many countries to determine whether a subject may be a carrier of non-A, non-B hepatitis. ${ }^{2}$ In the United Kingdom testing for hepatitis B core antibody is currently recommended only as follow up in cases of suspected post-transfusion hepatitis.

Although the number of cases we have reported is small, our findings are interesting as, firstly, in both cases of hepatitis B infection transmitted by transfusion a donor was positive for hepatitis B core antibody and 
had a history of hepatitis; and, secondly, in the three cases of infection not transmitted by transfusion all the donors were negative for hepatitis $B$ core antibody.

Blood donations are accepted by the National Blood Transfusion Service 12 months after an episode of jaundice or hepatitis in the donor so long as testing for hepatitis B surface antigen yields negative results. In the light of our findings and recent legislation relating to product liability we believe that this policy should be reassessed and that consideration should be given to testing such donors for hepatitis B core antibody and excluding them if they are found to be positive.

I Barbara JA. Microbiology in blood transfusion. London: Wright, 1983.

2 Menitove JE. Rationale for surrogate testing to detect non A non B hepatitis. Transfusion Medicine Review 1988;2:65-75.

3 Hoffnagle JH, Seeff LB, Bales ZB, Zimmerman HJ, and the Veterans Administration Hepatitis Cooperative Study. Type B hepatitis after transfusion with blood containing antibody to hepatitis B core antigen. N Engl f Med 1978;298:1379-83.

4 Cossart YE, Kirsch S, Ismay SL. Post transfusion hepatitis in Australia. Lancet 1982;i:208-13.

(Accepted 3I May 1989)

\section{Surgical footwear: a survey of prescribing consultants}

\author{
M Lord, J Foulston
}

Department of Mechanical Engineering, University College London, London WC1E 7JE

M Lord, MPHIL, lecturer

Department of Medical

Engineering and Physics,

King's College School of

Medicine and Dentistry,

Dulwich Hospital, London

SE22 8PT

J Foulston, MCHS, honorary

research fellow

Correspondence to:

Ms Lord.

BrMed f 1989;299:657 rheumatology and rehabilitation.
Changes are likely to occur in the present system by which patients obtain special footwear because of alterations in contractual aspects and the introduction of new technology such as digital shape capture and computerised design. ${ }^{12}$ Continuous, central records are not kept on the provision of footwear, though we have conservatively estimated that costs across the United Kingdom in 1986 were about $£ 12$ million. As a basis for the introduction of technological changes more information on the present system would be advantageous. Previous surveys have concentrated on the views of consumers. ${ }^{3+}$ We present a report on a survey into the system of supplying footwear from the point of view of most consultants in the United Kingdom who prescribe and accept the footwearnamely, those in diabetology, orthopaedics, and

\section{Methods and results}

A questionnaire requested background information about type of clinics, the current organisation of the delivery service, delegation in an ideal world, and respondents' perception of aspects of the service. We sent out 1696 questionnaires and $821(48.4 \%)$ were returned, response rates being 176/430 (40.9\%), $469 / 983(47 \cdot 7 \%)$, and $176 / 283(62 \cdot 2 \%)$ for diabetologists, orthopaedic surgeons, and rheumatologists respectively; 285 respondents volunteered written comments.

Many written comments emphasised dissatisfaction with the speed of delivery (table) with further indications on the desirability of a permanent workshop within the hospital or more frequent visits by fitters. With traditional methods of production this probably cannot be much improved. Even when factories meet the suggested maximum turn around time of six weeks from receipt of cast or measures to dispatch for trial fitting the overall supply time is probably too long by clinical criteria. The growing awareness of the availability of stock orthopaedic shoes may influence the future pattern of prescription. Use of off the shelf shoes of extra depth circumvents delays in fitting and provides a cheaper and more cosmetically acceptable alternative. Over a fifth of all consultants were dissatisfied with the suitability of the footwear (table). In addition, the cosmesis of surgical shoes was sometimes seen as poor. Some consultants suggested that free shoes may lead to abuse of the system and that a nominal charge should be made. The relationship between the consultant and fitter or patient and fitter was often commented on; many thought that a close relationship was needed. A general frustration with both logistic and training aspects was evident. There was evidence that financial pressures may be detrimental. The best contractor is sometimes the most expensive, and a change of contractoroften not necessarily in the patients' best interest - is occasionally initiated by restrictions on costs.

Responses to questions "Are you generally satisfied that footwear is suitable in practice for the purpose for which it is prescribed?" and "Are you generally satisfied with the speed of production of footwear?"

\begin{tabular}{lcr}
\hline & \multicolumn{2}{c}{ No(\%) of consultants satisfied with: } \\
\cline { 2 - 3 } Specialty & Suitability & \multicolumn{1}{c}{ Speed } \\
\hline Diabetology & $123 / 171(72)$ & $81 / 120(48)$ \\
Orthopaedics & $368 / 464(79)$ & $251 / 462(54)$ \\
Rheumatology and rehabilitation & $123 / 176(70)$ & $69 / 176(39)$ \\
\hline
\end{tabular}

Chiropodists play an important part in supplying footwear for diabetic patients, and diabetologists reported closer links with chiropodists than did other groups of consultants. Analysis of the data showed considerable geographical variations. Under a third of consultants were satisfied with speed in North West Thames compared with two thirds in the Northern region. Satisfaction with suitability varied from just over half in North West Thames to nearly complete in the Northern region.

\section{Comment}

With the event of clinical accounting in NHS hospitals consultants' requirements for the supply of footwear will become even more important in determining the contractor and type of footwear. Consultants have clearly indicated improvements necessary in the supply of surgical footwear, primarily in the speed of delivery, fitting, training of staff, and perhaps, in some cases, rationalisation of the system. Some concern was expressed over changes in contractors because of economic rather than clinical reasons. Under direct budgetary control criteria will tend towards cost-benefit rather than cost or benefit alone.

We thank the Department of Health and Social Security's supply division for financial support; Drs Arnold Bloom and Frank Dudley Hart and Professor Leslie Klenerman; Dr M Leaning, of the operational research unit, University College London, for help with analysis; and the consultants who took part in the survey. Copies of the full report may be obtained from $M L$.

1 Jones D. Impact of advanced manufacturing technology on prosthetic and orthotic practice. $\mathcal{F}$ Biomed Eng 1988;10:179-83.

2 Lord $M$, Jones $\mathrm{D}$. Issues and themes in computer aided design for external prosthetics and orthotics. $\mathcal{F}$ Biomed Eng 1988;10:491-8.

Office of Population Censuses and Surveys. National Health Service surgical footwear. A study of patient satisfaction. London: HMSO, 1979

4 Guthrie D. A future for the orthotic service: a report by the working party on the availability and supply of orthotic appliances. London: Royal Assuciation for availability and supply of orthotic appliances. London: Royal Association for
Disability and Rehabilitation, 1983 . (Accepted 26 June 1989) 